\title{
Oral and pharyngeal cancer in the North-west and West Yorkshire regions of England, and occupation
}

\author{
C. J. WhitAKer, E. MOSS, W. R. LEE, AND STElla CUNLIFFE \\ From the Department of Occupational Health, University of Manchester, Stopford Building, \\ Oxford Road, Manchester M13 9PT
}

\begin{abstract}
Patients with oral or pharyngeal cancer in the two main textile regions of England were matched for age and sex with patients having cancers not known to be associated with textile work. Data were recorded on age, sex, cancer site, and smoking, chewing and drinking habits together with dental and occupational history. There were 102 and 61 matched pairs of males and 52 and 60 matched pairs of females in the North-west and West Yorkshire regions respectively. There were significantly $(\mathrm{P}<0.05)$ more textile workers in the cases compared with their matched controls for only the females in the North-west. No particular type of textile work occurred more frequently for the cases than the controls in all four matched comparisons. Only for the males in the North-west were there significant differences $(P<0.05)$ in the proportions of textile workers in the three cancer sites of the tongue, mouth and pharynx. These results do not confirm the association between textile work and oral or pharyngeal cancer found by the mortality study of Moss and Lee (1974). The results for the association between oral or pharyngeal cancer and smoking, drinking, chewing and wearing of dentures are discussed.
\end{abstract}

A high incidence in both mortality and morbidity from oral and pharyngeal cancer among textile workers in England and Wales was noted by the Office of Population Censuses and Surveys in 1972. Later, Moss and Lee (1974) found a $77 \%$ excess of deaths from oral and pharyngeal cancers in male textile workers compared with the male population of England and Wales. This finding was based on the 31 deaths from oral and pharyngeal cancer of male textile workers aged 15-64 yr in 1959-63. Using this group, together with further data, they also showed that the excess appeared to be greatest in wool-fibre preparers. However, they advised caution about this conclusion which was based on a single set of numerators and compared with various denominators, adding that information on the mortality of female textile workers and on morbidity in both sexes was incomplete.

For these reasons the present morbidity surveys were undertaken for both males and females covering the two main textile regions of England and Wales. The regions are the North-west and West Yorkshire where, during the relevant period of exposure, the textile industry was based mainly

Received for publication 27 October 1978 Accepted for publication 20 March 1979 on cotton and wool respectively.

\section{Methods}

The survey used a case-control design. A patient with oral or pharyngeal cancer was matched with a patient of the same sex and within three years of the same age, with one exception of within five years of the same age. The cases of oral and pharyngeal cancer were classified according to the Eighth Revision of the International Classification of Diseases (World Health Organization, 1967) and grouped into malignant neoplasm of the tongue (ICD no. 141), the mouth (ICD nos. 143, 144 and 145 ) and the pharynx (ICD nos. 146, 147, 148 and 149). Only squamous-celled oral and pharyngeal cancers were included. The control patients had primary malignancies which are not known to be associated with textile work. Malignancies which were excluded were cancers of the bladder (Anthony and Thomas, 1970), skin (e.g. scrotal cancer, Lee et al., 1972), nasal cavity and sinuses (Acheson et al., 1972) and larynx (Stell and McGill, 1973). Cancers of the lung were also excluded. All the female control patients were attending hospital for post-operative radiotherapy of breast cancers. The male control group comprised mainly patients with 
Hodgkin's disease, lymphosarcoma, and cancer of the gastrointestinal tract, testis, salivary gland, lymphoid tissue and thyroid. Because all the patients had cancer, no question of non-susceptibility to cancer arises.

The first part of the survey was undertaken in the North-west region at Christie Hospital, Manchester. The female patients with oral or pharyngeal cancer were referred to us by the doctor treating them. The male patients were identified from the admissions list by EM, as were the male and female control subjcits. After identification all the patients were interviewed by WRL, using a questionnaire on age, sex, cancer site, and smoking, chewing and drinking habits together with dental and occupational history.
The second part of the survey was undertaken in the West Yorkshire region at Cookridge Hospital, Leeds. Here all four groups, i.e. male and female patients and controls, were identified from the admissions list of individual wards and then interviewed by $\mathrm{SC}$ using the same questionnaire.

\section{Results}

The numbers, mean ages and age ranges for each of the four matched comparisons are shown in Table 1. The occupations of the patients were classified according to the Classification of Occupations (Office of Population Censuses and Surveys, 1970). The occupations of the patients are shown in

Table 1 The numbers, mean ages and age ranges in the four matched comparisons

\begin{tabular}{|c|c|c|c|c|c|c|c|c|}
\hline \multirow[t]{3}{*}{ Variables } & \multicolumn{4}{|c|}{ North-west } & \multicolumn{4}{|c|}{ West Yorkshire } \\
\hline & \multicolumn{2}{|l|}{ Males } & \multicolumn{2}{|c|}{ Females } & \multicolumn{2}{|l|}{ Males } & \multicolumn{2}{|c|}{ Females } \\
\hline & Cases & Controls & Cases & Controls & Cases & Controls & Cases & Controls \\
\hline $\begin{array}{l}\text { Numbers } \\
\text { Mean ages } \\
\text { Age range }\end{array}$ & $\begin{array}{l}102 \\
64 \cdot 7 \\
25-85\end{array}$ & $\begin{array}{l}102 \\
64 \cdot 4 \\
25-86\end{array}$ & $\begin{array}{l}57 \\
66 \cdot 5 \\
42-90\end{array}$ & $\begin{array}{l}57 \\
66 \cdot 3 \\
43-85\end{array}$ & $\begin{array}{l}61 \\
61 \cdot 2 \\
18-85\end{array}$ & $\begin{array}{l}61 \\
61 \cdot 0 \\
17-85\end{array}$ & $\begin{array}{l}60 \\
67 \cdot 6 \\
47-87\end{array}$ & $\begin{array}{l}60 \\
67 \cdot 8 \\
47-86\end{array}$ \\
\hline
\end{tabular}

Table 2 The distribution of the main occupations in the four matched comparisons

\begin{tabular}{|c|c|c|c|c|c|c|c|c|c|}
\hline \multicolumn{2}{|c|}{$\begin{array}{l}\text { Main occupation, order number } \\
\text { and description }\end{array}$} & \multicolumn{4}{|l|}{ North-west } & \multicolumn{4}{|c|}{ West Yorkshire } \\
\hline & & \multicolumn{2}{|l|}{ Males } & \multicolumn{2}{|l|}{ Females } & \multicolumn{2}{|l|}{ Males } & \multicolumn{2}{|l|}{ Females } \\
\hline & & Cases & Controls & Cases & Controls & Cases & Controls & Cases & Controls \\
\hline I & Farmers & 5 & 8 & 1 & 7 & 4 & 3 & & 1 \\
\hline II & Miners & $8(1) *$ & 7 (2) & & & $1(1)$ & 8 & & \\
\hline III & Chemical & $3(2)$ & & & & 1 & & & \\
\hline IV & Glass \& Ceramics & & & 1 & & 1 & & & \\
\hline $\mathrm{v}$ & Furnace \& Foundry & $2(1)$ & 3 & & & 1 & & & \\
\hline & Electrical & 1 (1) & $5(2)$ & & & & & & \\
\hline VII & Engineering & 14 (2) & $10(2)$ & $1(1)$ & 1 & 6 & $7(2)$ & & 1 \\
\hline VIII & Woodworkers & & $3(1)$ & & & & 1 & & \\
\hline IX & Leather & $1(1)$ & & & & & & $1(1)$ & \\
\hline $\mathbf{x}$ & Textile & 7 & 8 & 25 & 16 & 7 & 7 & 13 & 16 \\
\hline $\mathbf{X I}$ & Clothing & 3 & 3 & 5 & 3 & & & 6 & $4(1)$ \\
\hline XII & Food, Drink, Tobacco & 2 & 4 & $4(1)$ & 2 & 1 & 1 & 1 & \\
\hline XIII & Paper \& Printing & & $2(1)$ & 1 & & 2 & 1 & & \\
\hline XIV & Other Products Makers & $3(1)$ & & & & $2(1)$ & 1 & & \\
\hline $\mathbf{X V}$ & Construction & 1 & 2 & & & 2 & $3(1)$ & & \\
\hline XVI & Painters & 3 & 1 & & & 3 & & & \\
\hline XVII & Stationary Engine Drivers & $1(1)$ & 2 & & & 1 & & & \\
\hline XVIII & Labourers N.E.C. $\ddagger$ & $7(3)$ & $4(1)$ & & & $6(1)$ & $6(2)$ & 1 & 1 \\
\hline XIX & Transport & $14(3)$ & $13(1)$ & & 1 & $5(2)$ & 7 (1) & 1 & 2 \\
\hline $\mathbf{X X}$ & Warehousemen & $1(1)$ & & $1(1)$ & & 3 & 2 & & 3 \\
\hline $\mathbf{X X I}$ & Clerical & 9 & 9 & 6 (1) & 8 & 5 & 3 & 6 & 5 \\
\hline XXII & Sales & 4 & 7 (2) & 2 & 3 & 3 & 3 & 5 & $4(1)$ \\
\hline XXIII & Service & $4(1)$ & 1 (1) & $9(3)$ & $9(3)$ & 2 & 2 & $25(3)$ & $15(5)$ \\
\hline XXIV & Managers & 2 & 1 & & & 3 & 1 & & \\
\hline $\mathbf{X X V}$ & Professional & 3 & $9(1)$ & & 4 & & 3 & & 6 \\
\hline \multirow[t]{3}{*}{ XXVI } & Armed Forces & 3 & & & & 2 & $2(1)$ & & \\
\hline & Not Employed & 1 & & 1 & 3 & & & 1 & 2 \\
\hline & $\begin{array}{l}\text { Total } \\
\text { Mean years in employment }\end{array}$ & $\begin{array}{l}102(18) \\
33 \cdot 5(7 \cdot 6) \dagger\end{array}$ & $\begin{aligned} & 102(14) \\
& 32 \cdot 4(7 \cdot 4)\end{aligned}$ & $\begin{array}{l}57(7) \\
24 \cdot 2(5 \cdot 9)\end{array}$ & $\begin{array}{l}57(3) \\
25 \cdot 1(6 \cdot 0)\end{array}$ & $\begin{array}{l}61(5) \\
33 \cdot 0(7 \cdot 0)\end{array}$ & $\begin{array}{l}61(7) \\
31 \cdot 9(6.4)\end{array}$ & $\begin{array}{l}60(4) \\
24 \cdot 6(7 \cdot 5)\end{array}$ & $\begin{array}{l}60(7) \\
23 \cdot 2(9 \cdot 1)\end{array}$ \\
\hline
\end{tabular}

* The number in parentheses represents the number of workers with secondary textile experience (i.e. main occupation as shown but also with two or more years in the textile industry).

The mean number of years in employment for those workers with secondary textile experience.

$\ddagger$ Not elsewhere classified. 
Table 3 Main fibre dealt with by those patients with at least two years' experience in textiles

\begin{tabular}{|c|c|c|c|c|c|c|c|c|}
\hline \multirow[t]{3}{*}{$\overline{\text { Main fibre }}$} & \multicolumn{4}{|c|}{ North-west } & \multicolumn{4}{|c|}{ West Yorkshire } \\
\hline & \multicolumn{2}{|l|}{ Males } & \multicolumn{2}{|c|}{ Females } & \multicolumn{2}{|l|}{ Males } & \multicolumn{2}{|c|}{ Females } \\
\hline & Cases & Controls & Cases & Controls & Cases & Controls & Cases & Controls \\
\hline Cotton & 24 & 17 & 28 & 18 & 2 & 1 & 2 & 4 \\
\hline Wool & - & 3 & 1 & - & 10 & 12 & 14 & 18 \\
\hline Other/man-made & 1 & 2 & 3 & 1 & - & - & 1 & 1 \\
\hline Total & 25 & 22 & 32 & 19 & 12 & $13^{*}$ & 17 & 23 \\
\hline
\end{tabular}

* One male control aged 17 with main occupation in textiles had only one year's service and so was not included in this and subsequent Tables in the group with textile experience (two years).

Table 2. The main occupation for a patient is the one in which most of the working life was spent. Table 2 also shows the number of patients with a secondary occupation in textiles. Patients were considered to have a secondary occupation in textiles if their main occupation had not been in textiles but nevertheless they had worked for at least two years in that industry. Textile experience was further classified into the unit groups in Occupational Order X (Textile Workers). As the numbers were so small, the unit groups were combined, as listed below, with occupations of a similar nature:

\section{Unit Group}

\section{Fibre preparers \\ 065 Spinners, Doublers, Twisters \\ 066 Winders, Reelers \\ 067 Warpers, Sizers, Drawers-in \\ 068 Weavers \\ 069 Knitters \\ 070 Bleachers and Finishers of Textiles \\ 071 Dyers of Textiles \\ 072 Textile fabrics and related products makers and examiners not elsewhere classified \\ 073 Textile fabrics, etc; production process workers not elsewhere classified}

Table 3 shows the patients grouped according to the textile fibre used, whether in a main or secondary occupation i.e. with at least two years in the textile industry. As expected, the majority of textile workers in the North-west worked with cotton, the remainder with wool and man-made fibres, while in West Yorkshire the majority of textile work was with wool, the remainder with cotton and man-made fibres. The matched pairs were then classified into four groups: where both the case and the matched control had two or more years of textile experience (Yes, Yes); where only the case had such experience (Yes, No); where only the control had such experi-
Table 4a The distribution of matched pairs with at least two years' experience in textiles, for the four matched comparisons

\begin{tabular}{|c|c|c|c|c|c|}
\hline \multirow{2}{*}{\multicolumn{2}{|c|}{$\begin{array}{l}\text { Textile worker } \\
\text { for } 2 \text { or more } \\
\text { years }\end{array}$}} & \multicolumn{2}{|c|}{ North-west } & \multicolumn{2}{|c|}{ West Yorkshire } \\
\hline & & & & & \\
\hline \multicolumn{2}{|c|}{ Cases Controls } & Males & Females & Males & Females \\
\hline $\begin{array}{l}\text { Yes } \\
\text { Yes } \\
\text { No } \\
\text { No }\end{array}$ & $\begin{array}{l}\text { Yes } \\
\text { No } \\
\text { Yes } \\
\text { No }\end{array}$ & $\begin{array}{r}9 \\
16 \\
13 \\
64\end{array}$ & $\begin{array}{r}14 \\
18 \\
5 \\
20\end{array}$ & $\begin{array}{r}3 \\
9 \\
10 \\
39\end{array}$ & $\begin{array}{r}12 \\
5 \\
11 \\
32\end{array}$ \\
\hline \multicolumn{2}{|l|}{ Total } & 102 & 57 & 61 & 60 \\
\hline \multicolumn{2}{|c|}{$\begin{array}{l}x^{2 *} \\
\text { df } \\
\text { Significance }\end{array}$} & $\begin{array}{c}0.14 \\
1 \\
0.7<P<\end{array}$ & $\begin{array}{l}6.26 \\
1 \\
80.01<P<0.02\end{array}$ & $\begin{array}{l}0 \\
1 \\
p>0.9\end{array}$ & $\begin{array}{l}1.56 \\
1 \\
0.2<P<0.3\end{array}$ \\
\hline
\end{tabular}

*McNemar's test using only the (Yes, No) and (No, Yes) pairs.

ence (No, Yes); and where neither the case nor control had such textile experience (No, No). The distribution of the matched pairs is shown in Table 4a. Using McNemar's test (Maxwell, 1961), which compares the number of (Yes, No) and (No, Yes) pairs, only the females in the North-west had significantly $(P<0.05)$ more textile workers in the cases than in the controls $\left(\chi^{2}=6.26\right.$; df $=1$;

Table 4b The distribution of matched pairs with at least ten years' experience in textiles, for the four matched comparisons

\begin{tabular}{|c|c|c|c|c|c|}
\hline \multicolumn{2}{|c|}{$\begin{array}{l}\text { Textile worker } \\
\text { for } 10 \text { or more } \\
\text { years }\end{array}$} & \multicolumn{2}{|c|}{ North-west } & \multicolumn{2}{|c|}{ West Yorkshire } \\
\hline \multicolumn{3}{|c|}{$\overline{\text { Cases Controls Males }}$} & Females & Males & Females \\
\hline $\begin{array}{l}\text { Yes } \\
\text { Yes } \\
\text { No } \\
\text { No }\end{array}$ & $\begin{array}{l}\text { Yes } \\
\text { No } \\
\text { Yes } \\
\text { No }\end{array}$ & $\begin{array}{r}1 \\
6 \\
7 \\
90\end{array}$ & $\begin{array}{r}4 \\
18 \\
5 \\
30\end{array}$ & $\begin{array}{r}2 \\
7 \\
6 \\
46\end{array}$ & $\begin{array}{r}5 \\
7 \\
10 \\
38\end{array}$ \\
\hline Total & & 102 & 57 & 61 & 60 \\
\hline $\begin{array}{l}x^{2 *} \\
\text { df } \\
\text { Signi }\end{array}$ & ficance & $\begin{array}{c}0 \\
1 \\
\mathbf{P}>0 \cdot 9\end{array}$ & $\begin{array}{c}6.26 \\
1 \\
0.01<P<0.02\end{array}$ & $\begin{array}{c}0 \\
1 \\
P>0.9\end{array}$ & $\begin{array}{l}0.24 \\
1 \\
0.5<P<0.7\end{array}$ \\
\hline
\end{tabular}

*McNemar's test using only the (Yes, No) and (No, Yes) pairs. 
Table 5a The distribution of male cases by cancer site and textile work, and of male controls by textile work

\begin{tabular}{|c|c|c|c|c|c|c|c|c|c|c|}
\hline \multirow[t]{3}{*}{ Occupation order $X$, unit group } & \multicolumn{5}{|c|}{ North-west } & \multicolumn{5}{|c|}{ West Yorkshire } \\
\hline & \multicolumn{4}{|l|}{ Cases } & \multirow{2}{*}{$\frac{\text { Controls }}{\text { Total }}$} & \multicolumn{4}{|l|}{ Cases } & \multirow{2}{*}{$\frac{\text { Controls }}{\text { Total }}$} \\
\hline & Tongue & Mouth & Pharynx & Total & & Tongue & Mouth & Pharynx & Total & \\
\hline 064 Fibre preparers & $\mathbf{0}$ & $\mathbf{0}$ & $\mathbf{0}$ & $\mathbf{0}$ & 2 & 1 & $\mathbf{0}$ & 0 & 1 & 3 \\
\hline 065-7 Spinners, etc. & 0 & 9 & 1 & 10 & 10 & 0 & 0 & 1 & 1 & 4 \\
\hline 068-9 Weavers/knitters & 1 & 3 & 0 & 4 & 3 & $\mathbf{0}$ & 1 & 0 & 1 & 1 \\
\hline 070-1 Bleachers/dyers & 0 & 4 & 1 & 5 & 4 & 1 & 2 & 0 & 3 & 0 \\
\hline 072-3 Others & 0 & 6 & 0 & 6 & 3 & 1 & 2 & 3 & 6 & 5 \\
\hline $\begin{array}{l}\text { Number with }>2 \text { years' textile experience } \\
\text { Number with }<2 \text { years' textile experience }\end{array}$ & $\begin{array}{r}1 \\
17\end{array}$ & $\begin{array}{l}22 \\
40\end{array}$ & $\begin{array}{r}2 \\
20\end{array}$ & $\begin{array}{l}25 \\
77\end{array}$ & $\begin{array}{l}22 \\
80\end{array}$ & $\begin{array}{r}3 \\
20\end{array}$ & $\begin{array}{r}5 \\
18\end{array}$ & $\begin{array}{r}4 \\
11\end{array}$ & $\begin{array}{l}12 \\
49\end{array}$ & $\begin{array}{l}13 \\
48\end{array}$ \\
\hline Tetal & 18 & 62 & 22 & 102 & 102 & 23 & 23 & 15 & 61 & 61 \\
\hline
\end{tabular}

Table 5b The distribution of female cases by cancer site and textile work, and of female controls by textile work

\begin{tabular}{|c|c|c|c|c|c|c|c|c|c|c|}
\hline \multirow[t]{3}{*}{ Cccupation order $X$, unit group } & \multicolumn{5}{|c|}{ North-west } & \multicolumn{5}{|c|}{ West Yorkshire } \\
\hline & \multicolumn{4}{|l|}{ Cases } & \multirow{2}{*}{$\frac{\text { Controls }}{\text { Total }}$} & \multicolumn{4}{|l|}{ Cases } & \multirow{2}{*}{$\frac{\text { Controls }}{\text { Total }}$} \\
\hline & Tongue & Mouth & Pharynx & Total & & Tongue & Mouth & Pharynx & Total & \\
\hline 064 Fibre preparers & 2 & 2 & 2 & 6 & 3 & 0 & 0 & 2 & 2 & 2 \\
\hline 065-7 Spinners, etc. & 1 & 5 & 6 & 12 & 6 & 3 & 1 & 5 & $\overline{9}$ & 10 \\
\hline 068-9 Weavers/knitters & 3 & 4 & 1 & 8 & 6 & 2 & 1 & 2 & 5 & 8 \\
\hline 070-1 Bleachers/dyers & 0 & 0 & $\mathbf{0}$ & 0 & 1 & $\mathbf{0}$ & 0 & $\mathbf{0}$ & 0 & 0 \\
\hline Number with $>2$ years' textile experience & 8 & 13 & 11 & 32 & 19 & 5 & 2 & 10 & 17 & 23 \\
\hline Number with $<2$ years' textile experience & 7 & 8 & 10 & 25 & 38 & 14 & 12 & 17 & 43 & 37 \\
\hline Total & 15 & 21 & 21 & 57 & 57 & 19 & 14 & 27 & 60 & 60 \\
\hline
\end{tabular}

$0.01<\mathrm{P}<0.02$ ). Table $4 \mathrm{~b}$, which shows similar results to Table $4 \mathrm{a}$, is obtained when the matched pairs are classified according to whether they had 10 or more years' textile experience. (The same $\chi^{2}$ test results for the females in the North-west are due to the coincidence that the same number of (Yes, No) and (No, Yes) pairs occur in Tables 4a and $b$.

Table 5a shows, for males, the distribution of all those patients with two or more years' textile experience by cancer site and textile unit group. Also shown are the distributions of the control subjects with similar textile experience by textile unit group, together with the distribution of those cases with less than two years' work in the textile industry, by cancer site. For each textile unit group there was no significant difference between the proportions of cases and controls in the North-west (Fisher's exact probability test, $\mathrm{P}>0.05$ in all five comparisons; Maxwell, 1961). When the ratio of cases with two or more years in textile work to cases without such experience was compared in the three cancer sites, a significant difference was found in the North-west $\left(\chi^{2}=10.38 ; \mathrm{df}=2 ; 0.001<\mathrm{P}\right.$ $<0.01$ ). However, no significant differences were found in West Yorkshire where, due to the small number, Fisher's exact probability test was used $(0.5<\mathrm{P}<0.7)$.

The corresponding results for the females are shown in Table 5b. In both the North-west and West Yorkshire no significant differences were found between the proportions of cases and controls in each textile unit group (Fisher's exact probability test, $P>0.05$ in all five comparisons). In addition, no significant difference was found in the three cancer sites between the ratios of cases with two or more years' textile experience to those without such

Table 6 The distribution of matched pairs by smoking, for the four matched comparisons

\begin{tabular}{|c|c|c|c|c|c|}
\hline \multirow{2}{*}{\multicolumn{2}{|c|}{$\frac{\overline{\text { Smoker }}}{\text { Cases Controls }}$}} & \multicolumn{2}{|c|}{ North-west } & \multicolumn{2}{|c|}{ West Yorkshire } \\
\hline & & Males & Females & Males & Females \\
\hline $\begin{array}{l}\text { Yes } \\
\text { Yes } \\
\text { No } \\
\text { No }\end{array}$ & $\begin{array}{l}\text { Yes } \\
\text { No } \\
\text { Yes } \\
\text { No }\end{array}$ & $\begin{array}{r}87 \\
14 \\
1 \\
0\end{array}$ & $\begin{array}{l}11 \\
14 \\
11 \\
21\end{array}$ & $\begin{array}{r}44 \\
10 \\
5 \\
2\end{array}$ & $\begin{array}{r}9 \\
11 \\
9 \\
31\end{array}$ \\
\hline \multicolumn{2}{|l|}{ Total } & 102 & 57 & 61 & 60 \\
\hline \multicolumn{2}{|c|}{$\begin{array}{l}\chi^{2 *} \\
\text { df } \\
\text { Significance }\end{array}$} & $\begin{array}{c}9.6 \\
1 \\
0.001<\end{array}$ & $\begin{array}{l}0.16 \\
1 \\
0.5<P<C\end{array}$ & $\begin{array}{c}1 \cdot 07 \\
1 \\
0 \cdot 3<P\end{array}$ & $\begin{array}{l}0.05 \\
1 \\
0.8<\mathrm{P}<0.9\end{array}$ \\
\hline
\end{tabular}

${ }^{*}$ McNemar's test using only the (Yes, No) and (No, Yes) pairs. 
experience for either the North-west $\left(\chi^{2}=0.45\right.$; df $=2 ; 0.7<\mathrm{P}<0.8)$ or West Yorkshire $\left(\chi^{2}=\right.$ $2.41 ; \mathrm{df}=2 ; 0.2<\mathrm{P}<0.3$ ).

The distribution of matched pairs by smoking habit is shown in Table 6. A smoker is a person who has smoked at least one cigarette per day, or a quarter-ounce $(7 \cdot 1 \mathrm{~g})$ of pipe tobacco per week, for at least one year. An ex-smoker is a former pipe or cigarette smoker who has not smoked for at least two years before hospital admission. For the purpose of this statistical analysis, the ex-smokers were grouped with the current smokers. Only for the males in the North-west are there significantly

Table 7 The distribution of matched pairs by drinking, for the four matched comparisons

\begin{tabular}{|c|c|c|c|c|c|}
\hline \multirow{2}{*}{\multicolumn{2}{|c|}{$\begin{array}{l}\text { Regular drinker } \\
\text { Cases Controls }\end{array}$}} & \multicolumn{2}{|c|}{ North-west } & \multicolumn{2}{|c|}{ West Yorkshire } \\
\hline & & Males & Females & Males & Females \\
\hline $\begin{array}{l}\text { Yes } \\
\text { Yes } \\
\text { No } \\
\text { No }\end{array}$ & $\begin{array}{l}\text { Yes } \\
\text { No } \\
\text { Yes } \\
\text { No }\end{array}$ & $\begin{array}{l}24 \\
42 \\
10 \\
26\end{array}$ & $\begin{array}{r}0 \\
6 \\
3 \\
48\end{array}$ & $\begin{array}{l}13 \\
21 \\
11 \\
16\end{array}$ & $\begin{array}{r}2 \\
8 \\
2 \\
48\end{array}$ \\
\hline \multicolumn{2}{|l|}{ Total } & 102 & 57 & 61 & 60 \\
\hline \multicolumn{2}{|c|}{$\begin{array}{l}\chi^{2 *} \\
\text { df } \\
\text { Significance }\end{array}$} & $\begin{array}{c}18.48 \\
1 \\
P<0.001\end{array}$ & $\begin{array}{l}0.44 \\
1 \\
0.5<P<0.7\end{array}$ & $\begin{array}{l}2 \cdot 53 \\
1 \\
0 \cdot 1<P\end{array}$ & $\begin{array}{l}2.5 \\
1 \\
20 \cdot 1<P<0.2\end{array}$ \\
\hline
\end{tabular}

*McNemar's test using only the (Yes, No) and (No, Yes) pairs. more smokers and ex-smokers in the cases than the controls $\left(\chi^{2}=9.6\right.$; $\left.\mathrm{df}=1 ; 0.001<\mathrm{P}<0.01\right)$.

Table 7 shows the distribution of the matched pairs by their stated drinking habits. Regular drinkers were defined as people who consume at least 1 pint of beer per day, or the alcoholic equivalent in spirits. One pint of beer is equivalent to 2 glasses of spirit (Graham et al., 1977) where 1 glass $=\frac{1}{6}$ gill $=24 \mathrm{ml}$. The results show that there were significantly more regular drinkers among the patients than the controls only for the males in the North-west $\left(\chi^{2}=\right.$ 18.48; $\mathrm{df}=1 ; \mathrm{P}<0.001$ ).

The smoking and drinking habits of the Northwest male patients and controls combined are shown in Table 8. Occasional drinkers were defined as people who consume less than seven pints of beer per week or the equivalent in spirits, so that they are people who usually drink at most three times per week, usually only at weekends. The results show that there is a significant association between the smoking and drinking habits $\left(\chi^{2}=24.83\right.$; df $=12 ; 0.01<P<0.02$ ).

Table 9a shows the distribution of matched pairs by the wearing of at least partial dentures. In none of the four comparisons is there a significant difference, between the cases and controls, in the numbers with dentures. When the number of years for which dentures had been worn was compared between the

Table 8 The distribution of the North-western male cases and controls by smoking and drinking habits

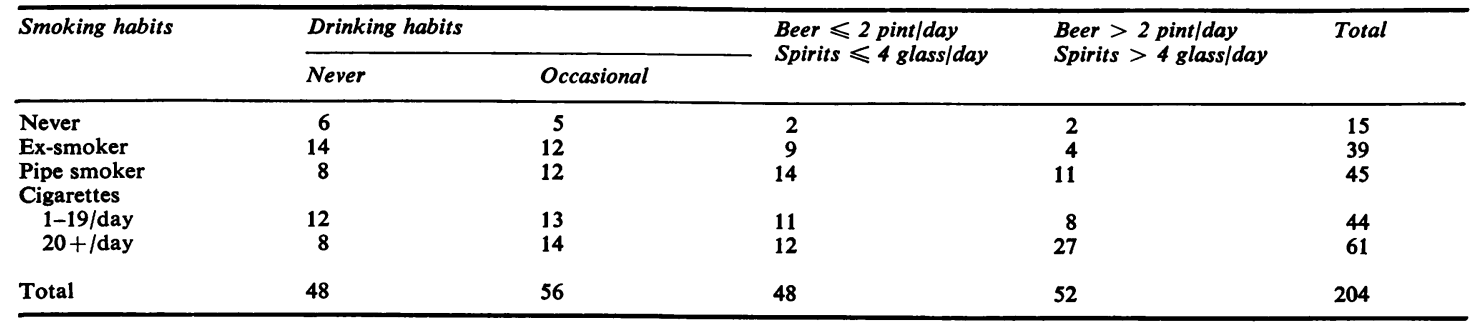

$x^{2}=24.83 ;$ df $=12 ; 0.01<$ P $<0.02$.

Table 9a The distribution of matched pairs by denture wearing, for the four matched comparisons

\begin{tabular}{|c|c|c|c|c|c|}
\hline \multicolumn{2}{|c|}{ Denture wearer } & \multicolumn{2}{|l|}{ North-west } & \multicolumn{2}{|l|}{ West Yorkshire } \\
\hline Cases & Controls & Males & Females & Males & Females \\
\hline $\begin{array}{l}\text { Yes } \\
\text { Yes } \\
\text { No } \\
\text { No }\end{array}$ & $\begin{array}{l}\text { Yes } \\
\text { No } \\
\text { Yes } \\
\text { No }\end{array}$ & $\begin{array}{r}64 \\
18 \\
13 \\
7\end{array}$ & $\begin{array}{r}54 \\
1 \\
2 \\
0\end{array}$ & $\begin{array}{r}35 \\
13 \\
8 \\
5\end{array}$ & $\begin{array}{r}49 \\
5 \\
6 \\
0\end{array}$ \\
\hline Total & & 102 & 57 & 61 & 60 \\
\hline $\begin{array}{l}x^{2 *} \\
\text { df } \\
\text { Significance }\end{array}$ & & $\begin{array}{l}0.52 \\
1 \\
0.3<P<0.5\end{array}$ & $\begin{array}{l}0 \\
1 \\
P>0.9\end{array}$ & $\begin{array}{l}0.76 \\
1 \\
0.3<P<0.5\end{array}$ & $\begin{array}{l}0 \\
1 \\
P>0.9\end{array}$ \\
\hline
\end{tabular}

*McNemar's test using only the (Yes, No) and (No, Yes) pairs. 
Table 9b The results of the Wilcoxon Signed Rank test for the number of years with dentures, for the four matched comparisons

\begin{tabular}{|c|c|c|c|c|c|c|c|c|}
\hline \multirow{3}{*}{$\begin{array}{l}\text { No. of years wearing } \\
\text { dentures }\end{array}$} & \multicolumn{4}{|c|}{ North-west } & \multicolumn{4}{|c|}{ West Yorkshire } \\
\hline & \multicolumn{2}{|l|}{ Males } & \multicolumn{2}{|c|}{ Females } & \multicolumn{2}{|l|}{ Males } & \multicolumn{2}{|c|}{ Females } \\
\hline & Cases & Controls & Cases & Controls & Cases & Controls & Cases & Controls \\
\hline $\begin{array}{l}\text { Median } \\
\text { Wilcoxon Test Z } \\
\text { Significance }\end{array}$ & 25 & $\begin{array}{l}27 \\
\cdot 5\end{array}$ & 35 & 34 & $\begin{array}{l}19 \\
0 \cdot 1\end{array}$ & $\begin{array}{l}16 \\
0 \cdot 2\end{array}$ & $\begin{array}{l}35 \\
0.3\end{array}$ & $\begin{array}{l}29 \\
0 \cdot 4\end{array}$ \\
\hline
\end{tabular}

cases and controls there was again no significant difference in any of the four comparisons (Table 9b).

The cases and controls were asked about any chewing habit. The materials chewed were gum (4 males, 2 females), tobacco $(20,0)$, pencils $(1,3)$, matchsticks $(1,0)$, cotton $(1,2)$ and herbs $(2,0)$. In none of the four comparisons is there a significant difference in the numbers of chewers between the patients and controls (Table 10a). When the comparison is restricted to tobacco chewers (all were males) there is still no significant difference in either of the two comparisons (Table 10b).

Table 10a The distribution of matched pairs by chewing, for the four matched comparisons

\begin{tabular}{|c|c|c|c|c|c|}
\hline \multirow{2}{*}{\multicolumn{2}{|c|}{$\frac{\text { Chewer }}{\text { Cases Controls }}$}} & \multicolumn{2}{|c|}{ North-west } & \multicolumn{2}{|c|}{ West Yorkshire } \\
\hline & & Males & Females & Males & Females \\
\hline $\begin{array}{l}\text { Yes } \\
\text { Yes } \\
\text { No } \\
\text { No }\end{array}$ & $\begin{array}{l}\text { Yes } \\
\text { No } \\
\text { Yes } \\
\text { No }\end{array}$ & $\begin{array}{r}0 \\
10 \\
7 \\
85\end{array}$ & $\begin{array}{r}0 \\
4 \\
2 \\
51\end{array}$ & $\begin{array}{r}1 \\
3 \\
8 \\
49\end{array}$ & $\begin{array}{r}\mathbf{0} \\
\mathbf{2} \\
1 \\
\mathbf{5 7}\end{array}$ \\
\hline \multicolumn{2}{|c|}{ Total } & 102 & 57 & 61 & 60 \\
\hline \multicolumn{2}{|c|}{$\begin{array}{l}\chi^{2 *} \\
\text { df } \\
\text { Significance }\end{array}$} & $\begin{array}{c}0.24 \\
1 \\
0.5<P\end{array}$ & $\begin{array}{l}0.17 \\
1 \\
0.5<P<0.7\end{array}$ & $\begin{array}{c}1 \cdot 45 \\
1 \\
0 \cdot 2<P\end{array}$ & $\begin{array}{c}0 \\
1 \\
P>0.9\end{array}$ \\
\hline
\end{tabular}

*McNemar's test using only the (Yes, No) and (No, Yes) pairs.

Table 10b The distribution of the matched pairs of males by tobacco chewing, for the two matched comparisons

\begin{tabular}{llll}
\hline Tobacco chewer & North-west & West Yorkshire \\
\hline Cases & Controls & & \\
\hline Yes Yes & 0 & 0 \\
Yes No & 8 & 2 \\
No Yes & 4 & 6 \\
No No & 90 & 53 \\
Total & 102 & 61 \\
$x^{2 *}$ & 0.75 & 1.13 \\
df & 1 & 1 \\
Significance & $0.3<P<0.5$ & $0.2<P<0.3$
\end{tabular}

* McNemar's test using only the (Yes, No) and (No, Yes) pairs .

\section{Discussion}

Tables $4 a$ and $b$ suggest that, only among the female textile workers in the North-west is there an excess of oral and pharyngeal cancer cases compared with the controls. Of the four comparisons, only the females in the North-west entered the study by referral from the clinicians in charge and not from the admissions list. However, a subsequent check revealed that, of 13 patients in the study during a six-month period, only one was not on the admissions list. There is, therefore, no reason to suppose that there was any deliberate selection of patients entering the study.

When the sites of oral and pharyngeal cancers are compared in patients with at least two years' textile experience, only the males in the North-west showed a significant difference, the excess being greatest in the mouth (Table 5a). This compares with the findings of Moss and Lee (1974) where there were significant excesses for the tongue and mouth. When comparing the type of textile work (unit group) and fibre used they found a significant excess among wool-fibre preparers. However, in this study there is no significant difference between the numbers of wool-fibre preparers in the patients and controls. Indeed, there is no difference in the ratio of patients to controls in any of the five textile unit groups in the North-west or in West Yorkshire.

Table 2 does not reveal any other occupational group with a consistent excess of patients over controls for both regions or both sexes and, therefore, does not suggest any other occupation that may involve the risk of oral or pharyngeal cancer.

The results of the smoking and drinking habits of the patients in the four studies are inconsistent for, while the males in the North-west with oral and pharyngeal cancer smoked and drank significantly more than their controls, the males in West Yorkshire did not show any significant differences. Nevertheless, the Tables do show greater numbers of smokers and drinkers in the West Yorkshire patients compared with the controls, and the nonsignificant results may be due, in some part, to the smaller number in the study. The same argument 
can be applied to the females, although there were fewer females who smoked or drank. Previous studies (Wynder et al., 1957; Keller, 1967) have found that smoking and drinking are significantly higher in oral and pharyngeal cancer cases when compared with controls. Smoking and drinking habits are associated (Wynder et al., 1957) and this has also been found in this study for the males in the North-west. Wynder and his colleagues found that the relative risks were approximately multiplicative and concluded that no synergy existed. However Graham et al. (1977) found that the excess risks were approximately additive and concluded that no synergy existed. Graham et al. and the references they cite can be consulted for details of the different definitions of synergy.

The wearing of dentures was common in all four studies and there was no significant difference between the patients and controls in this respect. This finding is similar to that of Wynder et al. (1957). Edentia was found by Wynder et al. to be more common among the oral and pharyngeal cases, but was not recorded in this investigation.

There is no significant difference in the chewing of tobacco or other materials between the patients and controls, but, because all the chewers also smoked, these two factors could not be disentangled. Moreover, there were so few chewers that chewing could play only a minor part, if any. Thus, the results for the effect of smoking, drinking, chewing and wearing of dentures are similar to those of previous studies.

The finding by Moss and Lee (1974) of an excess of textile workers with oral and pharyngeal cancer has not been confirmed by this investigation. A possible reason for the discrepancies, as stated by Moss and Lee, is that their investigation was a mortality study based on one set of numerators which was compared with various denominators. Furthermore, occupations recorded on death certificates are not always the best indicators of occupational history throughout working life.

The only significant excess found was for females in the North-west, a cotton area, which contrasts with the study of Moss and Lee where the excess was mainly in male wool workers, and possibly indicates that the finding in this study may be attributable to chance.

\section{Acknowledgements}

We are grateful to the British Cotton Growers Association for financial support for this investigation and to the medical staff and patients of Christie Hospital, Manchester and Cookridge Hospital, Leeds, for their help and co-operation.

\section{References}

Acheson, E. D., Cowdell, R. H., and Rang, E. (1972). Adenocarcinoma of the nasal cavity and sinuses in England and Wales. British Journal of Industrial Medicine, 29, 21-30.

Anthony, H. M., and Thomas, G. M. (1970). Tumors of the urinary bladder: an analysis of the occupations of 1030 patients in Leeds, England. Journal of the National Cancer Institute, 45, 879-895.

Graham, S., Dayal, H., Rohrer, T., Swanson, H., Sultz, H., Shedd, D., and Fischman, S. (1977). Dentition, diet, tobacco and alcohol in the epidemiology of oral cancer. Journal of the National Cancer Institute, 59, 1611-1616.

Keller, A. Z. (1967). Cirrhosis of the liver, alcoholism and heavy smoking associated with cancer of the mouth and pharynx. Cancer, 20, 1015-1022.

Lee, W. R., Alderson, M. R., and Downes, J. E. (1972). Scrotal cancer in the North-west of England, 1962-68. British Journal of Industrial Medicine, 29, 188-195.

Maxwell, A. E. (1961). Analysing Qualitative Data. Methuen: London.

Moss, E., and Lee, W. R. (1974). Occurrence of oral and pharyngeal cancers in textile workers. British Journal of Industrial Medicine, 31, 224-232.

Office of Population Censuses and Surveys (1970). Classification of Occupations. HMSO: London.

Office of Population Censuses and Surveys (1972). Studies on Medical and Population Subjects No. 23. Oral Cancer in England and Wales. Edited by W. H. Binnie, R. A. Cawson, G. B. Hill, and A. E. Soaper. HMSO: London.

Stell, P. M., and McGill, T. (1973). Asbestos and laryngeal carcinoma. Lancet, 2, 416-417.

World Health Organization (1967). Manual of the International Statistical Classification of Diseases, Injuries and Causes of Death, Eighth revision. WHO: Geneva.

Wynder, E. L., Bross, I. J., and Feldman, R. M. (1957). A study of the etiological factors in cancer of the mouth. Cancer, 10, 1300-1323. 